\title{
Challenges of Editing Latin Patristic Texts: A report from inside the Corpus Scriptorum Ecclesiasticorum Latinorum
}

Dorothea Weber

Google 'Ars edendi' on a computer in the Salzburg area, and one of the first sites to pop up is 'Ars edendi - the art of eating', by Monika Speier, a nutritionist from near Munich. Though eating and editing in Latin do not share the quantity of the first vowel, they do have some things in common. ${ }^{\mathrm{I}}$ For example, an editor is used to making collations, and so does everyone in Italy when having breakfast, the prima collazione. To ruminate is to both chew food and to think over a problem again and again - something that everyone producing an edition knows very well from experience, and finally the delight that results from a nice meal can be similar to the delight a well-produced edition gives to its user. The enjoyment of well-produced editions is not the least outcome of the Ars edendi project at Stockholm University. This large and excellent project is now reaching its end, and has made editors better aware of the possibilities, aims, risks and limits which they encounter in the editing of medieval texts.

\section{Editing Latin Texts from Late Antiquity}

With texts from Late Antiquity, some editorial issues are quite the same as with medieval, but others are not. Only within the last roo years have scholars come to understand Late Antiquity as a period of transformation when in politics, religion, arts, and literature, Europe and especially the Mediterranean areas turned away from the usual paths

This lecture was given at the Ars edendi concluding conference I9 August, 2016.

${ }^{1}$ As Michael W. Herren also commented in volume 2 of Ars Edendi Lecture Series.

How to cite this book chapter:

Weber, D. 2020. Challenges of Editing Latin Patristic Texts: A report from inside the Corpus Scriptorum Ecclesiasticorum Latinorum. In: Kihlman, E. and Searby, D. (eds.). Ars Edendi Lecture Series. vol. V. Pp. 89-I08. Stockholm: Stockholm University Press. DOI: https://doi.org/Io.I6993/bbd.f. License: CC-BY 
and patterns. ${ }^{2}$ The period in question began around the year 200 and, depending on regional developments in the different regions of the former Roman Empire, ended between the late fifth and the early seventh century. ${ }^{3}$ Classical philologists in the German speaking countries agree nowadays that the responsibility for editing and commenting on the Latin texts of that period, whether they be Christian or pagan, belongs to the field of classical philology, whereas previously only theologians studied the Christian literature of Late Antiquity. Moreover, that period was judged to be a time of deterioration and degeneration; researching it was regarded as investing time and energy in a culture that produced no art but only objects devoid of artistic value. ${ }^{4}$

Defining historical periods may often create more problems than it resolves, it is true. We may even suspect that establishing periods means no more than projecting the opinions of contemporary art criticism

${ }^{2}$ See Alexander Demandt, 'Die Spätantike als Epoche', in Spätantike. Mit einem Panorama der byzantinischen Literatur, Neues Handbuch der Literaturwissenschaft, Bd. 4, ed. by Lodewijk J. Engels and Heinz Hofmann (Wiesbaden: Aula Verlag, I997), pp. I-28. - Hartmut Leppin, Das Erbe der Antike, C.H. Beck Geschichte Europas I (München: C.H. Beck, 20Iо). - Alexander Demandt, Die Spätantike. Römische Geschichte von Diocletian bis Justinian 284 bis 565 n. Chr., Handbuch der Altertumswissenschaft III/6 (München: C.H. Beck, 2007²). - Idem, Geschichte der Spätantike. Das Römische Reich von Diocletian bis Justinian 284-565 n. Chr. (München: C.H. Beck, 2008²). - Idem, 'Die Zeitenwende von der Antike zum Mittelalter', in Von der Spätantike zum frühen Mittelalter: Kontinuitäten und Brüche, Konzeptionen und Befunde, ed. by Theo Kölzer (Ostfildern: Thorbecke, 2009), pp. I7-34. - Averil Cameron, The Mediterranean World in Late Antiquity: $A D$ 395-600 (London-New York: Routledge, 201 $2^{2}$; first edition I993):

3 Lodewijk J. Engels, 'Spätantike und lateinisches Mittelalter - ein rezeptionshistorischer Ausblick', in Spätantike. Mit einem Panorama der byzantinischen Literatur, Neues Handbuch der Literaturwissenschaft, Bd. 4, ed. by Lodewijk J. Engels and Heinz Hofmann (Wiesbaden: Aula Verlag, I997), pp. 60I-633. On different concepts and models of Late Antiquity see Scott Fitzgerald Johnson, 'On the Uniqueness of Late Antiquity', in The Oxford Handbook of Late Antiquity, ed. by Scott F. Johnson (Oxford: Oxford University Press, 20I 2), xi-xxiv.

4 See, for example, what Eduard Munk wrote about Sulpicius Severus in I86I, i.e., five years before CSEL vol. I (Sulpicii Severi Opera) came out: 'Die Noth der Zeit wirkte selbst erschlaffend auf die kirchliche Literatur. Die großen Kirchenlehrer des vorigen Jahrhunderts hatten keine würdigen Nachfolger. Das Mönchstum fand immer mehr Anhänger und Lobredner und mit mönchischer Beschränktheit erfaßten Sulpicius Severus ... und Paulus Orosius ... in ihren geschichtlichen Schriften die Vergangenheit und Gegenwart' (Geschichte der römischen Literatur, Dritter Teil: Geschichte der nach-classischen Literatur der Römer, Berlin, I86I, p. 294). - For a recent analysis of that concept of Late Antiquity cp. Clifford Ando, 'Narrating Decline and Fall', in A companion to Late Antiquity, ed. by Philipp Rousseau (Chichester: Wiley Blackwell, 2009), pp. 59-76, and Stefan Rebenich, 'Latin Antiquity in Modern Eyes', ibid., pp. 77-92. 
onto the past. Nevertheless, defining Late Antiquity as part of Antiquity, thus separating it from the Middle Ages, is somehow convenient from the viewpoint of research: tools which are most useful for doing research in classical Latin literature, for example, in the fields of history of literature, grammar, and language, ${ }^{5}$ are useful as well in dealing with phenomena of Late Antiquity. On the other hand, research on the culture of Late Antiquity does not differ much from research on Medieval culture, since both profit from and in fact are undertaken with the focus on interdisciplinarity. Apart from classicists, there are scholars of linguistics, history, theology, and Jewish Studies who are specialists in the issues of Late Antiquity.

For a classicist specialising in editing, Late Antiquity has some interesting new features: due to historical and cultural circumstances that favoured textual transmission, the extant literature of Late Antiquity represents far more varied artistic levels than in the case of classical literature. We have highly ambitious literature, for example, panegyrics to emperors or the pretentious and sophisticated letters of Ennodius, as well as primitive literary products such as, as early as from the end of the fourth century, the so-called Peregrinatio Egeriae or Aetheriae, ${ }^{6}$ a description by a nun named Egeria or Aetheria of her pilgrimage to the Holy Land, or monastic rules (Regula Magistri, Regula Benedicti, Regula Donati, etc.) from the sixth century onwards. In other and new aspects of everyday life a specific terminology developed, for example, the legal terminology necessary for the administration of the Roman Empire and the subsequent Germanic kingdoms, ${ }^{7}$ or the homiletic terminology. Each of these new developments generated specific customs and language patterns. Furthermore, borders between literary genres, formerly neatly separated, began to be blurred. Remember, for example, the Satura Menippea as used by Boethius in his Consolatio Philosophiae

5 Cf. the Thesaurus linguae Latinae (München, I90off.) and the Latin grammar by Manu Leumann, Johann Baptist Hofmann and Anton Szantyr, Lateinische Grammatik, 3 vols., Handbuch der Altertumswissenschaft 2, 2 (München: Beck, I972-I979²; reprint I997).

${ }^{6}$ This text is closely associated with the famous Swedish Latinist Einar Löfstedt, who as early as I9I I used the Peregrinatio as a basis for his fundamental analysis of the lexis, morphology, and syntax of Late Latin: Philologischer Kommentar zur Peregrinatio Aetheriae: Untersuchungen zur Geschichte der lateinischen Sprache (Uppsala: Alquist \& Wiksell, ı9 I ; several reprints).

E.g. Digestae, Institutiones, Novellae, Lex Romana Visigothorum; see Peter E. Pieler, 'Die Rechtsliteratur', in Spätantike. Mit einem Panorama der byzantinischen Literatur, Neues Handbuch der Literaturwissenschaft, Bd. 4, ed. by Lodewijk J. Engels and Heinz Hofmann (Wiesbaden: Aula-Verlag, I997), pp. 565-599. 
by which he refines the De nuptiis Mercurii et Philologiae by Martianus Capella. ${ }^{8}$ New genres appeared, as can be seen in Augustine of Hippo's Confessiones, which combine biographical elements and Bible exegesis. For some of these shifts, the emergence of Christianity seems to have been decisive. Thus, simple style and language were made respectable by the sermo piscatorius of the Bible. The genres of speech before a court or before a political gathering transformed into homilies, and the philosophical dispute eventually became a dispute against heretics.

It is evident, however, that in many respects Christian literature underwent the same changes as the non-Christian literature of the time. In fact, the distinction between them is nowadays judged as inappropriate because both reflect their position in regard to classical antiquity and recur to it in an almost identical way. This similarity results from the uniform institutional schools which were spread all over the Roman Empire. Since the contents of the curricula remained mostly as they had been and had not been Christianised, there was only one canon of literature and educational subjects that could be taken as default from Spain to Illyria and from North-Africa to Gaul. 9 The contacts with Greek literature of that time, however, gradually became looser, as the knowledge of Greek declined.

\section{The Foundation of CSEL in 1864}

The Corpus Scriptorum Ecclesiasticorum Latinorum (CSEL), therefore, has not limited itself to editing Christian Latin texts of Late Antiquity on the assumption that there is any essential difference in editing these texts and editing classical texts. On the contrary, the limitation to Christian text of Late Antiquity is due to the state of classical scholarship around the middle of the nineteenth century, when the long-term project of the CSEL was founded. ${ }^{\text {I० }}$ It was precisely at that time that the

${ }^{8}$ See, e.g., Danuta Shanzer, 'Interpreting the Consolation', in The Cambridge Companion to Boethius, ed. by John Marenbon (Cambridge: Cambridge University Press, 2009), pp. 228-254 (esp. 233sq.).

9 Cf. the comprehensive study of Henri Irénée Marrou, Histoire de l'éducation dans l'antiquité (Paris: Seuil, I948), and Konrad Vössing, Schule und Bildung im Nordafrika der Römischen Kaiserzeit (Bruxelles: Latomus, I997), pp. 7-22.

10 For the history of the CSEL see Rudolf Hanslik, 'Ioo Jahre Corpus Scriptorum Ecclesiasticorum Latinorum', in Anzeiger der philosophisch-historischen Klasse der Österreichischen Akademie der Wissenschaften, I I ( I964), 2 I-35; Michaela Zelzer, 'Ein Jahrhundert (und mehr) CSEL. Evaluation von Ziel und Veröffentlichungen', Sacris Erudiri, 38 (I998), 75-99; Dorothea Weber, 'I 50 Jahre Corpus Scriptorum Ecclesiasticorum Latinorum', in Edition und Erforschung lateinischer patristischer 
huge project of the Thesaurus linguae Latinae was in its planning stage. The scholars in charge did not feel comfortable with the idea that they would have to rely on outdated uncritical editions for Christian literature. This, in fact, was a problem since the 'Thesaurus' was designed to be a tool covering all the Latin literature of Antiquity. This is why the former imperial Academy of Sciences in Vienna, which was a partner in the 'Thesaurus' project, initiated a series of critical editions of the Latin church fathers. As Volume I it published Sulpicius Severus, ${ }^{\text {II }}$ with good reason. Apart from the Vita S. Martini, the works of Sulpicius are preserved in a single manuscript. Roughly the same is true for Arnobius' Adversus nationes, Volume $4 \cdot^{\mathrm{I2}}$ Thus, the new series started off at a rapid pace. Prior to the publication of Volume I, a catalogue of older manuscripts of the Latin Church Fathers was published to enable editors to save time when searching for manuscripts. ${ }^{\mathrm{I} 3}$ The catalogue, it is true, has been a useful tool for editors, although we are now far more cautious in attributing the highest value to the oldest manuscripts. I will come back to this. The editions of Sulpicius and Arnobius however are not typical for the work done at the CSEL. Especially with the big names, i.e. Ambrose, Jerome, Augustine and Gregory the Great, but even with others such as Juvencus' biblical epos, an editor has to deal with innumerable text witnesses. This is one of the major challenges we have to face. I will also return to this. In sum, it has become evident, I think, that the methods of the so-called New Philology ${ }^{\mathrm{I} 4}$ are not adequate for our texts, which in most instances are not texts that

Texte. I50 Jahre CSEL (FS Kurt Smolak), ed. by Victoria Zimmerl-Panagl, Lukas Dorfbauer and Clemens Weidmann (Berlin: De Gruyter, 20I4), ix-xi.

II Sulpicius Severus, Opera, ed. Karl Halm, CSEL I (Wien: Österreichische Akademie der Wissenschaften, I866).

I2 Arnobius, Adversusnationes, ed. August Reifferscheid, CSEL 4 (Wien: Österreichische Akademie der Wissenschaften, I875).

${ }^{13}$ Karl Halm, Verzeichniss der Älteren Handschriften lateinischer Kirchenväter in den Bibliotheken der Schweiz (Wien: Gerold in Comm., I 865).

${ }^{14}$ The term was coined in consequence of Bernard Cerquiglini's Éloge de la variante (Paris: Seuil, I989; trans. in I 999 into English: In Praise of the Variant), and since then has been discussed among medievalists, see, e.g., R. Howard Bloch, 'Introduction: The New Philology Comes of Age', in Rethinking the New Medievalism, ed. by R. Howard Bloch [et al.], (Baltimore [MD]: Johns Hopkins University Press, 20I4), pp. I-I I.; Gabrielle M. Spiegel, 'Reflections on The New Philology', ibid. 39-50. For a critical evaluation with regard to German Studies, see Freimut Löser, 'Postmodernes Mittelalter? New Philology und Überlieferungsgeschichte', in Kulturen des Manuskriptzeitalters, ed. by Arthur Groos [et al.], unter Mitarb. von Jochen Conzelmann (Göttingen: V \& R Unipress, 2004), pp. 2I 5-236. The concept of 'New Philology', though, has not had much impact on Late Antiquity studies. 
underwent systematic rescription, quite the contrary: they were held in esteem as authoritative and were thus not adapted freely. As a consequence, we generally apply stemmatic methods in our editions, even when it is impossible to design a stemma, as happens with text traditions that remain hopelessly contaminated.

\section{Glimpses of the Work done at CSEL}

I am now going to address some problems we have encountered in our most recent editing projects, some experiences we had and some solutions we found. I will do this without any systematic order and, of course, without the intention of completeness. Rather, every edition has challenges and problems of its own.

Whereas nowadays editors have at their disposal digital images of almost all manuscripts, our predecessors had to content themselves with microfilms. About 50 years ago, however, Rudolf Hanslik, at that time head of the CSEL, was in a far better situation since, when he ordered a microfilm of a Regula Benedicti codex from a library in Southern Italy, after a few weeks he received the manuscript itself in the post. In any case, the editors of Augustine, at that time the focus of the CSEL, in particular had to invest much time and energy in investigating the pertinent manuscripts. Therefore, Hanslik founded a series of publications intended to increase the speed of production and also the reliability of the editions. The series offers catalogues of manuscripts that transmit works attributed to St. Augustine. The series thus goes so far as to include writings falsely ascribed to Augustine. Starting with Italy, the series now comprises eleven volumes, thereby covering almost all European countries except France. ${ }^{15}$ The volumes aim at being exhaustive and are

\footnotetext{
${ }^{15}$ Die handschriftliche Überlieferung der Werke des Heiligen Augustinus, vol. I/I and I/2: 'Italien' by Manfred Oberleitner, Vienna I969 and I970 (SB ÖAW 263 and 267); vol. II/I and II/2: 'Großbritannien und Irland' by Franz Römer, Vienna I972 (ibid. 28I and 276); vol. III: 'Polen (Anhang: Die Skandinavischen Staaten Dänemark - Finnland - Schweden)' by Franz Römer, Vienna I973 (ibid. 289); vol. IV: 'Spanien und Portugal' by Johannes Divjak, Vienna I974 (ibid. 292); vol. V/I and V/2: 'Bundesrepublik Deutschland und Westberlin' by Rainer Kurz, Vienna I976 and 1979 (ibid. 306 and 350); vol. VI/I and VI/2: 'Österreich' by Dorothea Weber, Vienna I993 (ibid. 60I); vol. VII/I and VII/2: 'Tschechische Republik und Slowakische Republik’ by Clemens Weidmann, Vienna I997 (ibid. 645); vol. VIII/I and VIII/2: 'Belgien, Luxemburg und Niederlande' by Marie-Theres Wieser, Vienna 2000 (ibid. 68 5); vol. IX/I and IX/2: 'Schweiz', by Sarah Janner and Romain Jurot, Vienna 200I (ibid. 688); vol. X/I and X/2: 'Ostdeutschland und Berlin', by Isabella
} 
compiled on the basis of the autopsy of the manuscripts themselves; the catalogues are not simply compiled from other catalogues. This was intended in order to avoid reproducing any errors in previous catalogues. The project has not only provided a useful tool for editors in the volumes of this series, but has also led to new discoveries of some importance. Johannes Divjak, for example, discovered 29 new letters by Augustine - nowadays known as the Epistulae Divjak, in two French libraries, Paris and Marseille. ${ }^{16}$ Nine years ago, Isabella Schiller, while working on the volume of the former German Democratic Republic, identified six new sermons by Augustine in a twelfth-century manuscript in Erfurt. ${ }^{17}$ These sermons have subsequently been edited by Isabella Schiller, Clemens Weidmann and myself. ${ }^{18}$ To make an editio princeps of a sermon by an author as famous for his preaching as Augustine is a fascinating task. We have tried to reconstruct when, where, and under what circumstances the sermons were delivered, and to analyse their characteristics, the lines of thought and the structure of the arguments. We have had to deal with problems of textual criticism, it is true, but at the same time we had to help the readers to understand the spirit and temperament of the text by punctuating and organising it in paragraphs.

Remarkably enough, new texts have been discovered not only in very old manuscripts. To give two examples, Brian Møller Jensen discovered a new sermon by Augustine in a manuscript in Piacenza from the twelfth century, ${ }^{19}$ and the above-mentioned codex found in Marseille with the Epistulae Divjak originated as late as the fifteenth century. Thus, it becomes evident that we might miss new texts or at least good variants if we confine ourselves to the oldest text witnesses alone. Moreover, with pre-Carolingian manuscripts it may be the case that the texts they contain are even more corrupted than those that underwent correction in accordance with the Carolingian reforms. Even the famous Codex Petripolitanus from the early fifth century transmitting Augustine's De

Schiller, Vienna 2009 (ibid. 79I); vol. XI: 'Russland, Slowenien und Ungarn', by Irina Galynina [et al.], Vienna 20I0 (ibid. 809).

${ }^{16}$ Paris, Bibl. nat., lat. I686I (twelfth century), and Marseille, Bibl. mun. 209 (fifteenth century).

${ }^{17}$ Erfurt, University Library, Dep. Erf. CA. I $2^{\circ}$ I I.

18 Wiener Studien I 2 I (2008), 227-284 and I 22 (2009), I7 I-2I 3.

19 Ms. Piacenza, bibl. cap. 60, from the second half of the twelfth century; the text was edited by C. Weidmann in CSEL IoI (Wien: Österreichische Akademie der Wissenschaften, 20I 5), 3 I-44, as Augustini Sermo 59A. 
doctrina Christiana has some evident blunders, although it was written during Augustine's lifetime. ${ }^{20}$

Yet with the works transmitted to us in some old as well as in many younger manuscripts, it may prove impossible to collate all of them. In such cases we take sample collations in order to identify those manuscripts that transmit variants not attested by the older ones, since the younger manuscripts may be copied from older ones now lost. To establish text families, it may be useful not only to look at variant readings but also at the corpora of texts contained in the manuscripts, since the arrangement of texts was often retained. But even indirect text transmission may be very valuable. For example, when the Venerable Bede has a variant reading in a quotation from Augustine, we know that this variant is pre-Carolingian that may be lost in the extant Augustine manuscripts. At the same time texts which we are working on may cite others so that they attest variants not preserved by direct text transmission. Handling facts of this sort requires complex methodology and can lead to interesting results. I will present examples taken from three of our projects and which differ in their sets of problems and in the appropriate strategies for resolving them. I have deliberately chosen examples on a macro scale and others that pertain to single words only.

The most spectacular example is the recent discovery of the commentary on the Gospels by Fortunatianus, ${ }^{21}$ bishop of Aquileia in Northern Italy around the middle of the fourth century. Until then only three quotations of the text were known, two of them stemming from an exegetic compilation handed down in a manuscript from around I I OO in Troyes, the other from an exegetic anthology in a ninth century manuscript in Angers. In each of them the quotation is attributed to Fortunatus or Fortunatianus respectively.22 For all other information on Fortunatianus Jerome's De viris illustribus ch. 97 was the only source. In 20I2, when Lukas Dorfbauer, scholar at the CSEL, was browsing

\footnotetext{
${ }^{20}$ Lat. Q. v. I. 3, fifth century, described, e.g., in: Elias A. Lowe, Codices Latini Antiquiores, vol. I I (Oxford: Clarendon Press, I966), I6I3; Michael M. Gorman, The Manuscript traditions of the works of St. Augustine (Firenze, 200I), 260; Bernhard Bischoff, Katalog der festländischen Handschriften des neunten Jahrhunderts (mit Ausnahme der wisigotischen), Teil II: Laon - Paderborn. Aus dem Nachlaß hrsg. von Birgit Ebersperger (Wiesbaden, 2004), 23 I $7 \mathrm{~b}$.

${ }^{21}$ Edited by Lukas J. Dorfbauer, Fortunatianus Aquileiensis, Commentarii in Evangelia, CSEL IO3 (Wien: Österreichische Akademie der Wissenschaften, 20I7).

${ }_{22}$ Ms. Troyes, Bibl. mun. 653 (s. XI/XII): expositio Fortunati episcopi in eodem evangelio and expositio Fortunati episcopi ex eodem evangelio; Ms. Angers, Bibl. mun. 55 (s. IX): nunc vero de libro beati Fortunatiani Aquilegense episcopum aliqua testimonia scerpsimus quae hic congruit intimare.
} 
the digital library of the Dombibliothek at Cologne, he stumbled over a Gospel commentary lacking any indication of its author in codex I7 from the early ninth century. The text however could easily be dated to Late Antiquity, because quotations from the bible had the pre-Vulgate wording. Dorfbauer spotted the three quotations mentioned (cf. note 22), each of them in its appropriate context. Since the language of the text and its wording have striking characteristics, he was able to attribute the text beyond any doubt to Fortunatianus. Interestingly enough, the text seems to have been very much appreciated by later writers: it was cited quite frequently, but because the citations do not give any author, only now could they be identified. ${ }^{23}$

The constitutio textus becomes a really intricate task when the text to be edited consists of excerpts taken from other and earlier texts, as is the case of the monastic rule for nuns written by Donatus in the middle of the seventh century. This rule consists mostly of excerpts from the monastic rules of Caesarius of Arles, Columbanus and Benedict, which, apart from slight adaptations in the grammatical gender or number, are cited ad verbum. In the case of Donatus' rule, the main line of textual transmission, which consists in a single manuscript, the so-called Codex regularum, develops alongside with an extensive secondary transmission. However, the editor, Victoria Zimmerl-Panagl, ${ }^{24}$ took not only into account the wording of the preceding rules from the available editions but also all their variant readings, because it was impossible to identify the manuscripts used by Donatus. One textual problem which, though inconspicuous, can serve as an example of intertextuality as well as paratextuality is found in ch. 64 of Donatus's rule which consists of a single sentence by which, it seems, headgear is regulated. It reads: Capita numquam altiora ligent nisi quomodo in hoc loco mensuram

${ }^{23}$ It is interesting to observe that Lukas Dorfbauer dealt with problems of orthography similar to those Michael W. Herren ('Is the Author Really Better than his Scribes? Problems of Editing Pre-Carolingian Latin Texts', in Ars Edendi Lecture Series, vol. 2, ed. by Alessandra Bucossi and Erika Kihlman (Stockholm: Stockholm University Press, 2012), pp. 83-105) has pointed to with respect to Latin texts composed after c. 600 and before the Carolingian writing reforms and what Robert Burchard Constantijn Huygens, Ars Edendi: A Practical Introduction to Editing Medieval Latin Texts (Turnhout: Brepols, 2000), p. 4I, recommended for editing medieval texts: 'There are quite a number of factual, and even grammatical errors the editor should not correct, since it is by no means certain that the author himself cannot have made them.' See Dorfbauer, CSEL I03, pp. 89-98.

${ }^{24}$ The edition is published in CSEL 98: Monastica I (Donati Regula, PseudoColumbani Regula monialium [frg.]), ed. Victoria Zimmerl-Panagl (Wien: Österreichische Akademie der Wissenschaften, 20I 5 ). 
de incato fecimus (the edition by Holstenius from I66I has incausto instead of incato). ${ }^{25}$ This is almost completely identical with Caesarius' rule, ch. 56: Capita numquam altiora ligent quam in hoc loco mensuram de incausto (var. lect.: incato) fecimus. The word incatum is not attested elsewhere. Evidently, it is a variant of encaustum, the Latin

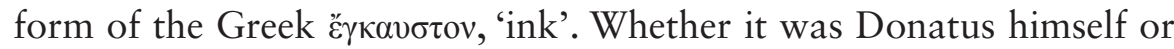
the scribe of the Codex regularum who wrote encatum can hardly be determined. Moreover, even in Caesarius both forms, encaustum and encatum, are transmitted, and interestingly enough incatum is the reading of the very same Codex regularum which is also the oldest extant manuscript of Caesarius' rule. Thus, the editor had to venture a guess: did the scribe of Donatus' rule write incatum because this was the reading of the manuscript he was copying? Or did he substitute incaustum with incatum according to the word he found in the rule of Caesarius? Or the other way round, did the scribe correct the word in the rule of Caesarius according to the rule of Donatus? Or does incatum occur in both rules only because this was the form the scribe was accustomed to, and incaustum is correct in both rules? In this case, the editor indicated with an asterisk in the critical apparatus that the decision to print incatum is still doubtful. ${ }^{26}$ Besides, some manuscripts display a line in the margin of that paragraph. We can guess that it was meant to indicate the height of the headdress. Alas, the length of the lines differs from manuscript to manuscript. In the Codex Regularum, it is $3.25 \mathrm{~cm}$ in the Donatus text and $5 \mathrm{~cm}$ in the Caesarius text. In another Caesarius manuscript in Tours which is now lost, it is said to have been $9.5 \mathrm{~cm} .{ }^{27}$

During my own work on Augustine's Contra Iulianum, I encountered a somewhat similar problem. Augustine wrote this work in the last decade of his life, as part of the discussion he had with Julian of Aeclanum, a follower of Pelagius, on original sin and on whether men can be completely free from sin or not. The first two books contain a collection of quotations from patristic writings that are meant to support the doctrine of original sin. In some of these quotations, the manuscripts of Contra Iulianum have the very same variant readings that can be found in the manuscripts transmitting the cited works. Some of these accordances might have come about by chance, it is true. For example, in Contra Iulianum 2, IO a quotation from Ambrose, In Lucam 7, I 42 is inserted that does not match exactly what seems to be the original text:

${ }_{25}$ 'They, i.e., the nuns, are not allowed to bind their heads higher than is indicated here with ink.'

${ }^{26}$ In the preface, the editor discussed this problem at p. I I $4 \mathrm{f}$.

${ }_{27}$ Ibid., p. II 4 . 
Augustinus, Contra Iulianum 2, IO:

Rursus in eodem opere, cum de spiritali atque incorruptibili loqueretur (scil. Ambrosius) cibo: „Etenim misericors cibus mentis est, inquit, praeclaraque alimonia suavitatis, quae membra non oneret neque in naturae pudenda, sed ornamenta convertat, cum libidinum volutabrum commutatur in dei templum diversoriumque vitiorum sacrarium incipit esse virtutum. ...

misericors] ratio Cod. Orléans BM I 62 (s. IX) cf. Ambrosius, in Luc. 7, I 42: ${ }^{28}$ ... etenim ratio cibus mentis est praeclaraque alimonia suavitatis. Quae membra non oneret neque in naturae pudenda, sed ornamenta convertat, cum libidinum volutabrum conmutatur in dei templum deversoriumque vitiorum sacrarium incipit esse virtutum. ...

ratio] var. lect.: rationibus, oratio oneret] var. lect.: haeret

oneret] haeret Cod. Orléans BM I 62 and eight other old mss.

Instead of oneret, one Ambrose manuscript as well as several of Augustine's Contra Iulianum have haeret which does not make sense. The error might have its origin in the preceding non or rather in its abbreviation, $\bar{n}$, and it may have come about in both text traditions independently ( $\bar{n}$ oneret misread as non eret). This type of explanation, however, is not appropriate for the other textual problem in the same passage. Since all the manuscripts of Augustine's work have etenim misericors cibus mentis est as the first words cited, only a single codex, though one of the oldest extant manuscripts, Orleans, Bibl. mun. I62 from the ninth century, cancelled out misericors and wrote ratio instead, which surely is the original reading in Ambrose. Most of the Ambrose manuscripts have ratio, few others have oratio or rationibus, but none have misericors or any other word which might even faintly resemble misericors. From this evidence we may conclude that misericors in Augustine is a varia lectio already present in Late Antiquity and that the scribe who corrected misericors to ratio in the Orleans manuscript did so because he had a manuscript of Ambrose at hand. In Contra Iulianum the correct text is therefore misericors, ${ }^{29}$ though

${ }^{28}$ CSEL 32/4: Ambrosius, Expositio evangelii secundum Lucan, by Karl Schenkl (Wien: Österreichische Akademie der Wissenschaften, I902).

29 Giovanni Paolo Maggioni discussed substantially similar problems in Iacobus' de Voragine Legenda aurea, see: Barbara Crostini - Gunilla Iversen - Brian Jensen (ed.), 
from the viewpoint of the Ambrose text this word is not what Ambrose wrote.

As already said, a good edition also must make the structure of the text visible. This can, but need not, be part of the constitutio textus in its traditional meaning. In this context, I am going to give examples from a large-scale project of the CSEL, the edition of Augustine's corpus of the Enarrationes in psalmos. ${ }^{\circ}$ I will not, however, deal with problems connected to the orality of the Enarrationes which consist largely of homilies. A preacher may, of course, make anacolutha and mental leaps, or it is possible that during the homily he spontaneously departs from his draft due to an unforeseen event - something that is normally difficult to reconstruct. ${ }^{3 \mathrm{I}}$ All of this is a major challenge for an editor, it is true. However, I just want to present one passage from Enarratio in Psalmum 65, 2-3 (commenting on ps. 65, I-2: [I] Iubilate deo omnis terra [2] psallite autem nomini eius) in order to show the extent to which punctuation and the insertion of paragraphs determines the character of the text. Many Enarrationes follow one and the same pattern: first a verse from the psalm - let it be called verse A - is cited, commented upon, and cited for a second time. Then the same pattern is applied to verse B: citation, commentary, citation, and so on. This is precisely the way the text of the Enarrationes is structured in vol. 36 of the monumental, though uncritical edition the Maurists made in Paris towards the end of the seventeenth century which was, with minor changes, reprinted in CC.SL 39:

(2) ... Inde coepit: Iubilate Deo. Qui? Omnis terra. Non ergo sola Judaea. Videte, fratres, quemadmodum commendetur universitas Ecclesiae toto

Ars Edendi Lecture Series, vol. 4 (Stockholm: Stockholm University Press, 2016), pp. 26-49.

30 So far nine out of twelve volumes are published in CSEL: Augustinus, Enarrationes in psalmos I-32 (expos.), by Clemens Weidmann, CSEL 93/IA (2003); I8-32 (Sermones), by Clemens Weidmann, CSEL 93/IB (20II); 5I-60, by Hildegund Müller, CSEL 94/I (2004); 6I-70, by Hildegund Müller, CSEL 94/2 (2020); IOI-I09, by Franco Gori, CSEL 95/I (20I I); I IO-I I 8, by Franco Gori, CSEL 95/2 (20I 5); II9-I33, by Franco Gori, CSEL 95/3 (200I); I34-I40, by Franco Gori, CSEL 95/4 (2002); I 4I-I 50, by Franco Gori, CSEL 95/5 (2005).

${ }_{31}$ This happened, for example, when Augustine delivered sermo $3{ }_{3} \mathrm{G}$ (=Erfurt 6; see Dorothea Weber, 'Sechs neue Augustinuspredigten. Teil I mit Edition dreier Sermones', Wiener Studien, I2 I [2008], 280-282). - On problems with editing medieval sermons see Nicole Bériou, 'Written Sermons and Actual Preaching: A Challenge for Editors', in Ars Edendi Lecture Series, vol. 2, ed. by Alessandra Bucossi and Erika Kihlman (Stockholm: Stockholm University Press, 2012), pp. 9-34. 
orbe diffusae; et non solum dolete Judaeos qui gratiam istam Gentibus invidebant, sed plus haereticos plangite. Si enim dolendi sunt qui collecti non sunt, quanto amplius qui collecti divisi sunt? Iubilate Deo, omnis terra. Quid est, Inbilate? In vocem erumpite gaudiorum, si non potestis verborum. Non enim verbis iubilatur; sed solus gaudentium sonitus redditur, quasi parturientis et parientis cordis laetitiam in vocem rei conceptae, quae verbis explicari non possit. Iubilate Deo, omnis terra: nemo iubilet in parte. Nemo, inquam, iubilet in parte: omnis terra iubilet, Catholica iubilet. Catholica totum tenet: quicumque partem tenet, et a toto praecisus est, ululare vult, non iubilare. iubilate Deo, omnis terra.

(3) Psallite autem nomini eius. Quid dixit? Psallentibus vobis benedicatur nomen eius. Quid sit autem psallere, heri dixi, et credo meminisse Caritatem Vestram. Psallere est organum etiam assumere quod psalterium dicitur, et pulsu atque opere manuum vocibus concordare. Si ergo iubilatis quod Deus audiat, psallite etiam quod homines et videant et audiant; ...

The text, however, does no longer resemble a didactic and somewhat tedious commentary and gains coherence when one inserts the paragraphs in slightly different positions, i.e. immediately after the commentary of a verse and before the repetition of the citation. Thus, the psalm is not cut into pieces totally isolated from each other, but has a continuous thread in which Augustine, as Hildegund Müller has shown convincingly, was far more interested than in the meaning of single verses. Then, verse A and $\mathrm{B}$ together introduce the commentary of verse $\mathrm{B}: \mathbf{3}^{2}$

(2) ... Inde coepit: IUBILATE DEO. qui? OMNIS TERRA: non ergo sola Iudaea. Videte, fratres, quemadmodum commendetur ... Catholica totum tenet: quicumque partem tenet et a toto praecisus est, ululare vult, non iubilare. iUbiLATE DeO OMNIS TERRA, (3) PSALLITE AUTEM NOMINI EIUS. Quid dixit? Psallentibus vobis benedicatur nomen eius. Quid sit autem psallere, heri dixi et credo meminisse Caritatem vestram. Psallere, est organum etiam assumere, quod psalterium dicitur, et pulsu atque opere manuum vocibus concordare. Si ergo iubilatis quod deus audiat, psallite etiam quod homines et videant et audiant. ...

Another startling discovery regarding the arrangement of the text was the outcome of Clemens Weidmann's work on the Enarrationes. ${ }^{33}$ This

${ }_{32}$ Text according to Hildegund Müller, Eine Psalmenpredigt über die Auferstehung: Augustinus, Enarratio in psalmum 65. Einleitung, Text, Übersetzung und Kommentar (Wien: Verlag der Österreichischen Akademie der Wissenschaften, I997).

33 The following example is taken from: Augustinus, Enarrationes in Psalmos I-32 (expos.), by Clemens Weidmann. CSEL 93/IA (Wien: Österreichische Akademie der Wissenschaften, 2003). 
Corpus, as already said, consists mostly of preached homilies; for psalms I to 32, however, it contains commentaries dictated by Augustine. Within this group, psalms I to I4 are commented upon verse by verse, whereas I 5 to 32 are rather paraphrased briefly in one or two sentences; only now and then an allegorical explanation is added. Clemens Weidmann was struck by the syntactical chaos and disorder of many of the paraphrastical explanations, e.g. in 29/I,7sq.:

(7) Ego autem dixi in abundantia mea, Non movebor in aeternum: ego autem ille populus, qui ab initio loquebar, dixi in mea abundantia, iam nullam patiens egestatem: Non movebor in aeternum. (8) Domine, in voluntate tua praestitisti decori meo virtutem: sed hanc abundantiam, Domine, non ex me mihi esse, sed in voluntate tua praestitisse te decori meo virtutem ex eo didici, Avertisti autem faciem tuam a me, et factus sum conturbatus; quod avertisti aliquando a peccante faciem tuam, et factus sum conturbatus, recedente a me illuminatione notitiae tuae.

Sed hanc abundantiam does not fit well with the preceding psalm verse (Domine, in voluntate tua praestitisti decori meo virtutem), and the logical structure of the rest, i.e. ex eo didici: Avertisti autem faciem tuam a me, et factus sum conturbatus, quod avertisti aliquando a peccante faciem tuam, is not clear at all. Passages like this make perfect sense if one removes those quotations that are meant as lemmata, so that the text under discussion reads: ego autem - ille populus, qui ab initio loquebar - dixi in mea abundantia iam nullam patiens egestatem: ,non movebor in aeternum. Sed hanc abundantiam, domine, non ex me mibi esse, sed in voluntate tua praestitisse te decori meo virtutem ex eo didici, quod avertisti aliquando a peccante faciem tuam. It is only thanks to this that quod avertisti can be identified so as depending on ex eo. Furthermore, in a manuscript from Echternach from the eleventh century, ${ }^{34}$ Clemens Weidmann found the remains of a numeric reference system. On this basis, he was able to reconstruct the text as follows: in Enarrationes I 5-32 each psalm is first quoted in its full length, its verses are numbered all the way through. Then, in the explanation Augustine refers to the pertinent verse not by citing it but only by its number. We know that Augustine used this reference system in his Contra sermonem Arrianorum and the Breviculus collationis cum Donatistis. Hence, in CSEL 93/IA the text is constituted as follows:

34 Paris, BnF, lat.I983 (PII in Weidmann's edition). 
$\langle$ XII $\rangle$ EGO AUTEM DIXI IN MEA ABUNDANTIA: 'NON MOVEBOR IN AETERNUM'.

〈XIII〉 DOMINE, IN VOLUNTATE TUA PRAESTITISTI DECORI MEO VIRTUTEM;

$\langle$ XIIII $\rangle$ AVERTISTI AUTEM

FACIEM TUAM A ME, ET FACTUS SUM CONTURBATUS. $\langle$ XII $\rangle$ Ego autem - ille populus qui ab initio loquebar - dixi in mea abundantia iam nullam patiens egestatem: ,NON MOVEBOR IN AETERNUM'. $\langle$ XIII $\rangle$ Sed hanc abundantiam, domine, non ex me mihi esse, sed in voluntate tua praestitisse te decori meo virtutem ex eo didici, 〈XIIII quod avertisti aliquando a peccante faciem tuam, et factus sum conturbatus recedente a me illuminatione notitiae tuae.

Again, it is worth noting that only one manuscript from the eleventh century has preserved part of the original reference system. If the editor had considered only the manuscripts predating the year Iooo-about 20 from before the eleventh century - he would not have been able to reconstruct the original arrangement of the text.

\section{The organisation of the CSEL}

Up to 2OI 2 the CSEL was funded and the editions were published by the Austrian Academy of Sciences. Since 20I 2 the CSEL has been part of the Department of Classics at Salzburg University, and the publisher is De Gruyter. The office, however, is still in Vienna. Our focus is on Augustine and Ambrose, but only as a guideline. Thus, within recent years, we have also published editions of an anonymous commentary on Job, two volumes on Prosper of Aquitaine, and the volume on Donatus mentioned above. The CSEL has volumes edited by the staff as well as by external editors. External editors receive advice and supervision whenever needed. Each volume is reviewed first by the CSEL staff, then by the advisory board, before it goes into print. Last but not least, the staff regularly gives courses on palaeography and editorial work in order to hand down the relevant skills and ultimately the pleasure of producing editions to the next generation of researchers.

\section{Bibliography}

Ando, Clifford, 'Narrating Decline and Fall', in A companion to Late Antiquity, ed. by Philipp Rousseau (Chichester: Wiley-Blackwell, 2009), pp. 59-76. 
Augustinus, Enarrationes in psalmos I-32 (expos.), by Clemens Weidmann, CSEL 93/IA (2003); I 8-32 (Sermones), by Clemens Weidmann, CSEL 93/ІB (20II); 5 I-60, by Hildegund Müller, CSEL 94/I (2004); IOI-IO9, by Franco Gori, CSEL 95/I (20II); I Io-I I 8, by Franco Gori, CSEL 95/2 (20I 5); I I9-I33, by Franco Gori, CSEL 95/3 (200I); I34-I40, by Franco Gori, CSEL 95/4 (2002); I4I-I 50, by Franco Gori, CSEL 95/5 (2005) (Wien: Österreichische Akademie der Wissenschaften).

Bériou, Nicole, 'Written Sermons and Actual Preaching: A Challenge for Editors', in Ars Edendi Lecture Series, vol. 2, ed. by Alessandra Bucossi and Erika Kihlman (Stockholm: Stockholm University Press, 20I 2), pp. 9-34.

Bischoff, Bernhard, Katalog der festländischen Handschriften des neunten Jahrhunderts (mit Ausnahme der wisigotischen), Teil II: Laon - Paderborn. Aus dem Nachlass hrsg. von Birgit Ebersperger (Wiesbaden: Harrassowitz, 2004).

Bloch, R. Howard, 'Introduction: The New Philology Comes of Age', in Rethinking the New Medievalism, ed. by R. Howard Bloch [et al.], (Baltimore [MD]: Johns Hopkins University Press, 20I4), pp. I-I I.

Cameron, Averil, The Mediterranean World in Late Antiquity: AD 395-600 (London-New York: Routledge, 20 I2²; first edition I993).

Cerquiglini, Bernard, Éloge de la variante: Histoire critique de la philologie (Paris: Seuil, I989); trans. in 1999 into English: In Praise of the Variant: A Critical History of Philology (Baltimore: Johns Hopkins University Press, I999).

Demandt, Alexander, 'Die Spätantike als Epoche', in Spätantike. Mit einem Panorama der byzantinischen Literatur, Neues Handbuch der Literaturwissenschaft, Bd. 4, ed. by Lodewijk J. Engels and Heinz Hofmann (Wiesbaden: Aula Verlag, I997), pp. I-28.

Demandt, Alexander, Die Spätantike. Römische Geschichte von Diocletian bis Justinian 284 bis $565 \mathrm{n}$. Chr. (Handbuch der Altertumswissenschaft III/6) (München: C.H. Beck, 2007²).

Demandt, Alexander, Geschichte der Spätantike. Das Römische Reich von Diocletian bis Justinian 284-565 n. Chr. (München: C.H. Beck, 2008²).

Demandt, Alexander, 'Die Zeitenwende von der Antike zum Mittelalter', in Von der Spätantike zum frühen Mittelalter: Kontinuitäten und Brüche, Konzeptionen und Befunde, ed. by Theo Kölzer (Ostfildern: Thorbecke, 2009), pp. I7-34.

Dorfbauer, Lukas J., ed., Fortunatianus Aquileiensis, Commentarii in Evangelia, CSEL I03 (Wien: Österreichische Akademie der Wissenschaften, 20I7). 
Engels, Lodewijk J., 'Spätantike und lateinisches Mittelalter - ein rezeptionshistorischer Ausblick', in Spätantike. Mit einem Panorama der byzantinischen Literatur, Neues Handbuch der Literaturwissenschaft, Bd. 4, ed. by Lodewijk J. Engels and Heinz Hofmann (Wiesbaden: Aula Verlag, I997), pp. 60I-633.

Gorman, Michael M., The manuscript traditions of the works of St. Augustine (Firenze: SISMEL, 200I).

Halm, Karl, Verzeichniss der Älteren Handschriften lateinischer Kirchenväter in den Bibliotheken der Schweiz (Wien: Gerold in Comm., I 865).

Halm, Karl, ed., Sulpicius Severus, Opera, CSEL I (Wien: Österreichische Akademie der Wissenschaften, I 866).

Hanslik, Rudolf, 'Ioo Jahre Corpus Scriptorum Ecclesiasticorum Latinorum', in Anzeiger der philosophisch-historischen Klasse der Österreichischen Akademie der Wissenschaften, IOI (I964), 2I-35.

Herren, Michael W., 'Is the Author Really Better than his Scribes? Problems of Editing Pre-Carolingian Latin Texts', in Ars Edendi Lecture Series, vol. 2, ed. by Alessandra Bucossi and Erika Kihlman (Stockholm: Stockholm University Press, 20I2), pp. 83-105.

Huygens, Robert Burchard Constantijn, Ars Edendi: A Practical Introduction to Editing Medieval Latin Texts (Turnhout: Brepols, 2000).

HÜWA Die handschriftliche Überlieferung der Werke des Heiligen Augustinus, vol. I/I and I/2: 'Italien' by Manfred Oberleitner, Wien I969 and I970 (SB ÖAW 263 and 267); vol. II/I and II/2: 'Großbritannien und Irland' by Franz Römer, Wien 1972 (ibid. 28I and 276); vol. III: 'Polen (Anhang: Die Skandinavischen Staaten Dänemark - Finnland - Schweden)' by Franz Römer, Wien I973 (ibid. 289); vol. IV: 'Spanien und Portugal' by Johannes Divjak, Wien 1974 (ibid. 292); vol.V/I and V/2: 'Bundesrepublik Deutschland und Westberlin' by Rainer Kurz, Wien 1976 and I 979 (ibid. 306 and 350); vol. VI/I and VI/2: 'Österreich' by Dorothea Weber, Vienna I 993 (ibid. 60I); vol. VII/I and VII/2: 'Tschechische Republik und Slowakische Republik' by Clemens Weidmann, Wien 1997 (ibid. 645); vol. VIII/I and VIII/2: 'Belgien, Luxemburg und Niederlande' by Marie-Theres Wieser, Wien 2000 (ibid. 685); vol. IX/I and IX/2: 'Schweiz', by Sarah Janner and Romain Jurot, Wien 200I (ibid. 688); vol. X/I and X/2: 'Ostdeutschland und Berlin', by Isabella Schiller, Wien 2009 (ibid. 79I); vol. XI: 'Russland, Slowenien und Ungarn', by Irina Galynina [et al.], Wien 2010 (ibid. 809).

Johnson, Scott Fitzgerald, 'On the Uniqueness of Late Antiquity', in The Oxford Handbook of Late Antiquity, ed. by Scott F. Johnson (Oxford: Oxford University Press, 20I 2), xi-xxiv. 
Leppin, Hartmut, Das Erbe der Antike, C.H. Beck Geschichte Europas I (München: C.H. Beck, 20IO).

Leumann, Manu - Hofmann, Johann Baptist - Szantyr, Anton, Lateinische Grammatik, 3 vols., Handbuch der Altertumswissenschaft 2, 2 (München: C.H. Beck, I972-I979²; reprint I997).

Löfstedt, Einar, Philologischer Kommentar zur Peregrinatio Aetheriae: Untersuchungen zur Geschichte der lateinischen Sprache (Uppsala: Almquist \& Wiksell, I9I I; several reprints).

Löser, Freimut, 'Postmodernes Mittelalter? New Philology und Überlieferungsgeschichte', in Kulturen des Manuskriptzeitalters, ed. by Arthur Groos [et al.], unter Mitarb. von Jochen Conzelmann (Göttingen: V \& R Unipress, 2004), pp. 2I 5-236.

Lowe, Elias A., Codices Latini Antiquiores, vol. I I (Oxford: Clarendon Press, I966).

Maggioni, Giovanni Paolo, 'Editing Errors', in Ars Edendi Lecture Series, vol. 4, ed. by Barbara Crostini, Gunilla Iversen and Brian Jensen (Stockholm: Stockholm University Press, 2016), pp. 26-49.

Marrou, Henri Irénée, Histoire de l'éducation dans l'antiquité (Paris: Éd. du Seuil, I948).

Müller, Hildegund, Eine Psalmenpredigt über die Auferstehung: Augustinus, Enarratio in psalmum 65. Einleitung, Text, Übersetzung und Kommentar (Wien: Verlag der Österreichischen Akademie der Wissenschaften, I997).

Munk, Eduard, Geschichte der römischen Literatur, Dritter Teil: Geschichte der nach-classischen Literatur der Römer (Berlin, I86I).

Pieler, Peter E., 'Die Rechtsliteratur', in Spätantike. Mit einem Panorama der byzantinischen Literatur, Neues Handbuch der Literaturwissenschaft, Bd. 4, ed. by Lodewijk J. Engels and Heinz Hofmann (Wiesbaden: Aula-Verlag, I997), pp. 565-599.

Rebenich, Stefan, 'Latin Antiquity in Modern Eyes', in A companion to Late Antiquity, ed. by Philipp Rousseau (Chichester: Wiley Blackwell, 2009), pp. 77-92.

Reifferscheid, August, ed., Arnobius, Adversus nationes, CSEL 4 (Wien: Österreichische Akademie der Wissenschaften, I 875 ).

Schenkl, Karl, ed., Ambrosius, Expositio evangelii secundum Lucan, CSEL 32/4 (Wien: Österreichische Akademie der Wissenschaften, I902).

Schiller, Isabella - Weber, Dorothea - Weidmann, Clemens, 'Sechs neue Augustinuspredigten. Teil I mit Edition dreier Sermones', Wiener Studien, I 2 I (2008), 227-284. 
Schiller, Isabella - Weber, Dorothea - Weidmann, Clemens, 'Sechs neue Augustinuspredigten. Teil 2 mit Edition dreier Sermones zum Thema Almosen', Wiener Studien, I 22 (2009), I 7 I-2 I3.

Shanzer, Danuta, 'Interpreting the Consolation', in The Cambridge Companion to Boethius, ed. by John Marenbon (Cambridge: Cambridge University Press, 2009), pp. 228-254.

Spiegel, Gabrielle M., 'Reflections on The New Philology', in Rethinking the New Medievalism, ed. by R. Howard Bloch [et al.], (Baltimore [MD]: Johns Hopkins University Press, 20I4), pp. 39-50.

Vössing, Konrad, Schule und Bildung im Nordafrika der Römischen Kaiserzeit (Bruxelles: Latomus, I997).

Weber, Dorothea, 'I 50 Jahre Corpus Scriptorum Ecclesiasticorum Latinorum', in Edition und Erforschung lateinischer patristischer Texte. I 5 o Jahre CSEL (FS Kurt Smolak), ed. by Victoria Zimmerl-Panagl, Lukas Dorfbauer and Clemens Weidmann (Berlin: De Gruyter, 20I4), ix-xi.

Zelzer, Michaela, 'Ein Jahrhundert (und mehr) CSEL. Evaluation von Ziel und Veröffentlichungen', Sacris Erudiri, 38 (I998), 75-99.

Zimmerl-Panagl, Victoria, ed., Monastica I (Donati Regula, Pseudo-Columbani Regula monalium [frg.]), CSEL 98 (Wien: Österreichische Akademie der Wissenschaften, 2015). 